\title{
Dupilumab elicits a favorable response in type-2 inflammatory comorbidities of severe atopic dermatitis
}

\author{
Eustachio Nettis ${ }^{1 *}$, Lucia Masciopinto ${ }^{1}$, Elisabetta Di Leo ${ }^{2}$, Nicola De Candia ${ }^{3}$, Marcello Albanesi ${ }^{1}$, \\ Danilo Di Bona ${ }^{1}$, Nicola Quaranta ${ }^{3}$ and Luigi Macchia ${ }^{1}$
}

\begin{abstract}
Background: This case is the first report describing rapid, successful treatment of severe atopic dermatitis (AD) and comorbid type-2 inflammatory diseases in the same patient, with dupilumab treatment, with no side-effects.

Case presentation: We report on effects of dupilumab in a patient with severe $A D$, a long-standing history of a mild, perennial allergic rhino-conjunctivitis, moderate asthma and chronic rhinosinusitis with nasal polyps (CRSwNP).

Conclusions: Patients suffering from AD, asthma, allergic rhinitis and CRSWNP may be eligible for dupilumab single treatment that is possibly advantageous also from the pharmaco-economic standpoint.
\end{abstract}

Keywords: Monoclonal antibody, Precision medicine, Asthma, Nasal polyps, Rhinoconjuctivitis

\section{Background}

Dupilumab is a monoclonal antibody against interleukin (IL)-4 receptor alpha, that inhibits IL-4/IL-13 signalling [1]. The latter cytokines have been implicated in numerous type-2 atopic/allergic conditions, including asthma, atopic dermatitis (AD) and nasal polyposis, often associated as comorbidities [2, 3]. Dupilumab is approved in the USA and in the European Union for patients aged 12 years or older with moderate-to-severe $\mathrm{AD}$ and in many Countries for patients with other type-2 inflammatory diseases [3].

\section{Case presentation}

Here, we report on effects of dupilumab in a patient with severe $\mathrm{AD}$, a long-standing history of a mild, perennial allergic rhino-conjunctivitis, moderate asthma and

\footnotetext{
*Correspondence: ambulatorio.allergologia@uniba.it

${ }^{1}$ Department of Emergency and Organ Transplantation, School

of Allergology and Clinical Immunology, University of Bari Aldo Moro, Policlinico Di Bari, Bari, Italy

Full list of author information is available at the end of the article
}

chronic rhinosinusitis with nasal polyps (CRSwNP). The patient was a 43-year-old Caucasian woman who had suffered from AD since early infancy and had undergone various treatments, including topical, nasal and inhaled corticosteroids, topical calcineurin inhibitors, antihistamines, leukotriene receptor antagonists, cyclosporin and systemic corticosteroids. She had also undergone surgical excision of bilateral nasal polyps, 10 years before. At the time of presentation, the patient's daily medication consisted of potent topical steroids (clobetasol propionate ointment $0.05 \%$ twice a day), desloratadine $(5 \mathrm{mg}$ ) and combination therapy consisting of inhaled beclometasone $(200 \mu \mathrm{g})$ and formoterol fumarate $(6 \mu \mathrm{g})$, two inhalations twice daily. She also had developed 2 severe $\mathrm{AD}$ exacerbations, requiring systemic corticosteroids during the 4 months before starting dupilumab treatment.

\section{Methods}

AD and type-2 comorbidities were evaluated with a full battery of tests, including: the Eczema Area and Severity Index (EASI); SCOring AD (SCORAD); Investigator's Global Assessment (IGA); peak scores on the pruritus

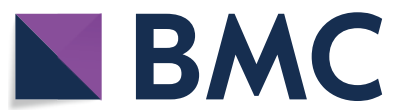

(c) The Author(s) 2021. This article is licensed under a Creative Commons Attribution 4.0 International License, which permits use, sharing, adaptation, distribution and reproduction in any medium or format, as long as you give appropriate credit to the original author(s) and the source, provide a link to the Creative Commons licence, and indicate if changes were made. The images or other third party material in this article are included in the article's Creative Commons licence, unless indicated otherwise in a credit line to the material. If material is not included in the article's Creative Commons licence and your intended use is not permitted by statutory regulation or exceeds the permitted use, you will need to obtain permission directly from the copyright holder. To view a copy of this licence, visit http://creativecommons.org/licenses/by/4.0/. The Creative Commons Public Domain Dedication waiver (http://creativecommons.org/publicdomain/zero/1.0/) applies to the data made available in this article, unless otherwise stated in a credit line to the data. 
numerical rating scale (NRS) and on the sleep NRS during the past 7 days; Patient-Oriented Eczema Measure (POEM); Dermatology Life Quality Index (DLQI); spirometry, Asthma Control Test (ACT); 5-question Asthma Control Questionnaire (ACQ-5); Standardised Asthma Quality of Life (QoL) Questionnaire (AQLQ[S]); 22-item Sino-Nasal Outcome Test (SNOT-22); endoscopic nasal polyp score (ENPS), assessed for each nostril, separately by endoscopy and graded on polyp size, yielding scores from 0 to 4; Loss of Smell Score; Rhinosinusitis Disease Severity; Rhinoconjunctivitis QoL Questionnaire (RQLQ); and complete ear, nose and throat examinations. Skin prick tests (SPT) were performed with common inhalants. Total IgE and a peripheral blood eosinophil count were also detected.

Dupilumab was administered with a 600-mg loading dose followed by a $300 \mathrm{mg}$ dose every 2 weeks, to control symptoms. The patient underwent follow-up examinations at weeks 4, 8, 12 and 16, after starting dupilumab therapy. During the follow-up period, the patient was asked to continue her pre-treatment therapy. Clinical characteristics of the patient at baseline and during dupilumab treatment are presented in Table 1 . At the last follow-up assessment, 16 weeks later, dupilumab

Table 1 Clinical characteristics of the patient at baseline and during dupilumab treatment (with concomitant medications)

\begin{tabular}{|c|c|c|c|c|c|}
\hline & Basal & 4 week & 8 week & 12 week & 16 week \\
\hline EASI score (scale 0-72) & 29 & 12.5 & 4.6 & 4 & 4 \\
\hline $\begin{array}{l}\text { SCORAD-total score } \\
\text { (scale } 0-103 \text { ) }\end{array}$ & 78 & 40.9 & 45.5 & 20 & 16 \\
\hline IGA score (scale 0-4) & 4 & 3 & 3 & 2 & 2 \\
\hline $\begin{array}{l}\text { NRS pruritus score } \\
\text { (scale 0-10) }\end{array}$ & 8 & 3 & 8 & 2 & 1 \\
\hline $\begin{array}{l}\text { NRS sleep score (scale } \\
0-10)\end{array}$ & 9 & 1 & 8 & 1 & 1 \\
\hline $\begin{array}{l}\text { POEM score (scale } \\
0-30)\end{array}$ & 21 & 2 & 20 & 2 & 2 \\
\hline DLQI score (scale 0-28) & 13 & 15 & 7 & 1 & 1 \\
\hline FEV1 (L) & 2.60 & 2.48 & 2.5 & 2.5 & 2.72 \\
\hline FEV1 (\% predicted) & $89.4 \%$ & $84 \%$ & $85 \%$ & $85 \%$ & $93.3 \%$ \\
\hline ACT score (scale 0-25) & 21 & 24 & 25 & 25 & 25 \\
\hline ACQ-5 score (scale 0-6) & 0.9 & 0.7 & 0.1 & 0.0 & 0.0 \\
\hline AQLQ score (scale 0-7) & 6.3 & 6.6 & 6.8 & 6.7 & 6.7 \\
\hline $\begin{array}{l}\text { Bilateral ENPS (scale } \\
0-8)\end{array}$ & 3 & - & - & - & 0 \\
\hline $\begin{array}{l}\text { SNOT-22 score (scale } \\
0-110)\end{array}$ & 20 & 14 & 12 & 15 & 11 \\
\hline $\begin{array}{l}\text { Loss of smell score } \\
\quad \text { (scale 0-3) }\end{array}$ & 2 & 2 & 1 & 1 & 1 \\
\hline $\begin{array}{l}\text { Rhinitis disease severity } \\
\text { (visual analog scale } \\
0-10 \mathrm{~cm} \text { ) }\end{array}$ & 6 & 5 & 3 & 3 & 2 \\
\hline RQLQ (scale 0-6) & 2.85 & 2.64 & 2.51 & 2.64 & 2.31 \\
\hline Total IgE levels, KUA/L & 1633 kUA/L & - & - & - & $901.8 \mathrm{kUA} / \mathrm{L}$ \\
\hline $\begin{array}{l}\text { Blood eosinophil Count, } \\
\text { cells } / \mu\end{array}$ & 239/mm3 & - & - & - & $50 / \mathrm{mm} 3$ \\
\hline $\begin{array}{l}\text { Concomitant medica- } \\
\text { tions }\end{array}$ & $\begin{array}{l}\text { Clobetasol proprion- } \\
\text { ate oinment 0.05\%, } 2 \\
\text { times a day; } \\
\text { Desloratadine } 5 \mathrm{mg} / \mathrm{die} \text {; } \\
\text { Beclomethasone/ } \\
\text { formoterol fumarate } \\
(200 / 6 \mu \mathrm{g}) \text { two inhala- } \\
\text { tions twice daily }\end{array}$ & $\begin{array}{l}\text { Desloratadine } 5 \text { mg as } \\
\text { needed; Beclometha- } \\
\text { sone/formoterol } \\
\text { fumarate }(200 / 6 \mu \mathrm{g}) \\
\text { one inhalation twice } \\
\text { daily }\end{array}$ & $\begin{array}{l}\text { Desloratadine } 5 \mathrm{mg} \text { as } \\
\text { needed; Beclometha- } \\
\text { sone/formoterol } \\
\text { fumarate }(100 / 6 \mu \mathrm{g}) \\
\text { one inhalation twice } \\
\text { daily }\end{array}$ & $\begin{array}{l}\text { Beclomethasone/ } \\
\text { formoterol fumarate } \\
(100 / 6 \mu \mathrm{g}) \text { one inha- } \\
\text { lation twice daily }\end{array}$ & $\begin{array}{l}\text { Beclomethasone/ } \\
\text { formoterol fuma- } \\
\text { rate }(100 / 6 \mu \mathrm{g}) \\
\text { one inhalation as } \\
\text { needed }\end{array}$ \\
\hline
\end{tabular}

ACQ-5, Asthma Control Questionnaire (5 items); ACT, Asthma Control Test; AQLQ (S), Asthma Quality of Life Questionnaire (standardized version); DLQI, Dermatology Life Quality Index; EASI, Eczema Area and Severity Index; ENPS, Endoscopic nasal polyp score; FEV1, Forced Expiratory Volume in $1 \mathrm{~s}$; IGA, Investigator's Global Assessment; NRS, Numerical Rating Scale; POEM, Patient-Oriented Eczema Measure; RCSS, Rhinitis Control Scoring System; RQLQ, Rhinitis Quality of Life Questionnaire; SCORAD, Scoring Atopic Dermatitis; SNOT-22, 22-item Sino-Nasal Outcome 

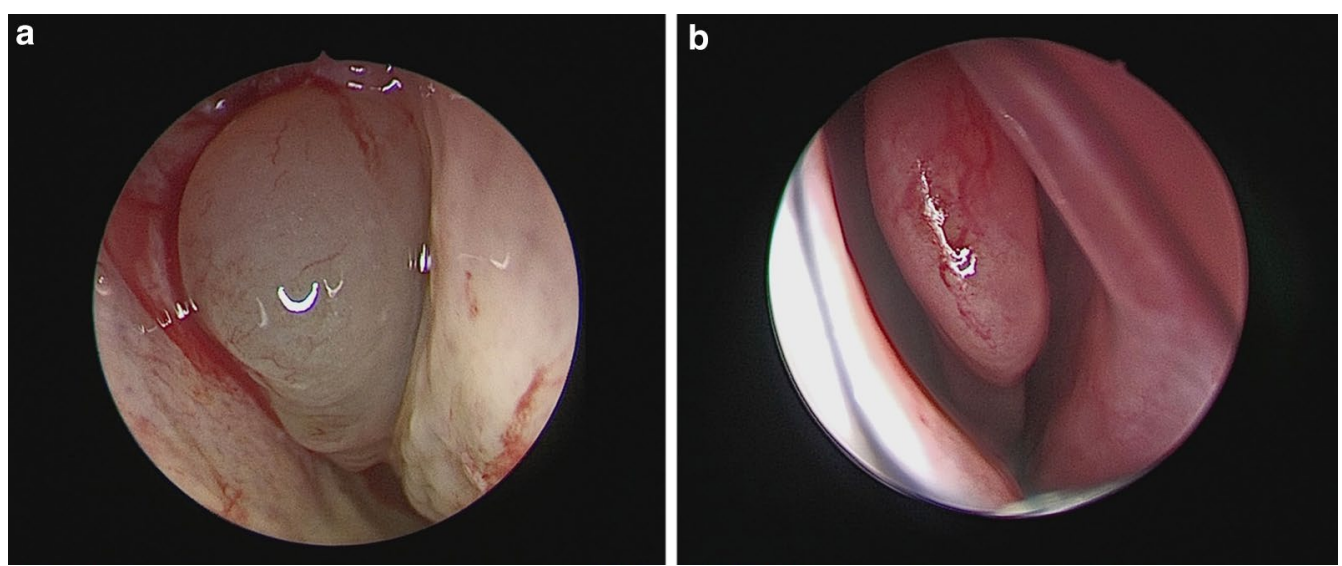

Fig. 1 a Endoscopic Nasal Polyp Score at baseline for the right side = 2 points; $\mathbf{b}$ Endoscopic Nasal Polyp Score at week 16 for the right side $=0$ points

had resulted in reduction in EASI score (4 points vs 29), SCORAD score (16 points vs 78 ) and IGA score (2 points vs 4 ), indicating a clinically relevant improvement. In addition, dupilumab reduced patient-reported symptoms of $\mathrm{AD}$ and its effects on QoL, sleep and pruritus. In fact, for both the POEM and DLQI scores, a reduction in the total score by 19 and 12 points, respectively, was recorded. By week 16, an improvement of 7 points in the peak score for pruritus NRS and 8 points for the sleep NRS had occurred. There were no significant changes in spirometry, ACT, ACQ-5 and AQLQ. The ENPS at baseline was 1 on the left side $(1=$ small polyps in the middle meatus not reaching below the inferior border of the middle turbinate) and 2 on the right side $(2=$ polyps reaching below the lower border of the middle turbinate) (Fig. 1a). After 16 weeks, her ENPS was 0 on both the right side (Fig. 1b) and the left side. Furthermore, at week 16 substantial improvements in the total SNOT-22 score (11 points vs 20 ), in the loss of smell score (2 points vs 1 ), in Rhinosinusitis Disease Severity assessed by visual analog scale (6 points vs 2 ) and in the RQLQ score (2.31 points vs 2.85 points) were observed. Moreover SNOT22 and RQLQ items are frequently rated by patients with sino-nasal disorders as important items affecting their health and QoL. SPT were positive for cat epithelium and house dust mites and clinically relevant. Our patient was able to discontinue topical corticosteroids and showed a reduction in the use of antihistamines and asthma combination therapy throughout the 16-week treatment period (Table 1). She no longer took systemic corticosteroids. Moreover no dupilumab-related side effects were reported.

Finally, a substantial reduction in peripheral eosinophil count was observed (Table 1).
$\mathrm{AD}$, a common chronic pruritic inflammatory skin disease, has a strong impact on patients' QoL [4]. Comorbidities, such as allergic rhinitis, asthma and CRSwNP are reportedly associated with a reduced health-related QoL [5]. Several studies have shown an important role of type-2 immunity in the immunopathology of $\mathrm{AD}$ and related comorbidities $[1-3,6]$. The keystone cytokines in type- 2 immune response include: IL-4, IL-5, IL-9 and IL-13 [7, 8]. In recent years, the development of therapies against targeting these cytokines has represented a significant advance in the treatment of these diseases. Dupilumab is directed against the alpha subunit of the IL-4 receptor, thereby blocking both IL-4 and IL-13 signalling and hence type-2 inflammation [6]. This explains the good response to dupilumab treatment in our patient with associated type- 2 inflammatory diseases. Infact, dupilumab proved effective in $\mathrm{AD}$ and ameliorated asthma and allergic rhinitis, as indicated by drug consumption, reducing the need for drugs. Notably, dupilumab was effective in reducing nasal polyps, as shown by ENPS (Table 1).

To our knowledge, this case is the first report describing rapid, successful treatment of severe AD and comorbid type- 2 inflammatory diseases in the same patient, with dupilumab treatment, with no side-effects. In conclusion, we suggest that patients suffering from AD, asthma, allergic rhinitis and CRSwNP may be eligible for dupilumab single treatment that is possibly advantageous also from the pharmaco-economic standpoint.

\section{Acknowledgements}

Not applicable.

Authors' contributions

All authors read and approved the final manuscript. 


\section{Funding}

There is no funding to declare.

\section{Availability of data and materials}

Not applicable.

\section{Declarations}

Ethics approval and consent to participate

Not applicable.

\section{Consent for publication}

Not applicable.

\section{Competing interests}

The authors declare that they have no competing interests.

\section{Author details}

'Department of Emergency and Organ Transplantation, School of Allergology and Clinical Immunology, University of Bari Aldo Moro, Policlinico Di Bari, Bari, Italy. ${ }^{2}$ Section of Allergy and Clinical Immunology, Unit of Internal Medicine - "F. Miulli" Hospital, Acquaviva Delle Fonti, Bari, Italy. ${ }^{3}$ Department of Neuroscience and Sensory Organs, Otolaryngology Unit, University of Bari Aldo Moro, Policlinico Di Bari, Bari, Italy.

Received: 6 October 2020 Accepted: 23 April 2021

Published online: 16 June 2021

\section{References}

1. Corren J, Castro M, O'Riordan T, Hanania NA, Pavord ID, Quirce $\mathrm{S}$, et al. Dupilumab efficacy in patients with uncontrolled, moderate-to-severe allergic asthma. J Allergy Clin Immunol Pract. 2019;S2213-2198(19):30775-85.

2. Eyerich S, Metz M, Bossios A, Eyerich K. New biological treatments for asthma and skin allergies. Allergy. 2019;75:546.

3. Bachert C, Hellings PW, Mullol J, Hamilos DL, Gevaert P, Naclerio RM, et al. Dupilumab improves health-related quality of life in patients with chronic rhinosinusitis with nasal polyposis. Allergy. 2019;75:148.

4. Fishbein AB, Silverberg Jl, Wilson EJ, Ong PY. Update on AD: diagnosis, severity assessment, and treatment selection. J Allergy Clin Immunol Pract. 2019;8:91.

5. Kok WL, Yew YW, Thng TG. Comorbidities associated with severity of atopic dermatitis in young adult males: a national cohort study. Acta Derm Venereol. 2019;99(7):652-6.

6. Harb H, Chatila TA. Mechanisms of Dupilumab. Clin Exp Allergy. 2019;50:5.

7. Oliphant CJ, Barlow JL, McKenzie AN. Insights into the initiation of type 2 immune responses. Immunology. 2011;134(4):378-85.

8. Wynn TA. Type 2 cytokines: mechanisms and therapeutic strategies. Nat Rev Immunol. 2015;15(5):271-82.

\section{Publisher's Note}

Springer Nature remains neutral with regard to jurisdictional claims in published maps and institutional affiliations.
Ready to submit your research? Choose BMC and benefit from:

- fast, convenient online submission

- thorough peer review by experienced researchers in your field

- rapid publication on acceptance

- support for research data, including large and complex data types

- gold Open Access which fosters wider collaboration and increased citations

- maximum visibility for your research: over 100M website views per year

At BMC, research is always in progress.

Learn more biomedcentral.com/submissions 